\title{
Atomic Spectroscopy S \\ Determination of Major, Minor and Trace Metallic Constituents in Sillimanite: Comparative Evaluation of EDXRF and D. C. Arc Carrier Distillation AES
}

\author{
Sk. Jayabun, ${ }^{\mathrm{a}}$ Sunita Pathak, ${ }^{\mathrm{a}}$ and Arijit Sengupta, ${ }^{\mathrm{a}, \mathrm{b}, *}$ \\ ${ }^{a}$ Radiochemistry Division, Bhabha Atomic Research Centre, Mumbai 400085, India \\ ${ }^{\text {b }}$ Homi Bhabha National Institute, Mumbai 400094, India \\ Received: Jun. 02, 2020; Revised: Jul.11, 2020; Accepted: Jul. 11, 2020; Published: Aug. 01, 2020.
}

DOI: $10.46770 / A S .2020 .04 .004$

ABSTRACT: An attempt was made to determine the major, minor and trace levels of common metallic constituents in sillimanite minerals. Direct current arc atomic emission spectrometry (D. C. Arc AES) and energy dispersive X-ray fluorescence spectrometry (EDXRF) were used for the comparative evaluation. $\mathrm{Al}$ and $\mathrm{Si}$ were found to be present as major matrix elements, whereas $\mathrm{Na}, \mathrm{Pb}, \mathrm{Tb}, \mathrm{Mn}, \mathrm{V}, \mathrm{Ti}, \mathrm{Ca}, \mathrm{Mo}, \mathrm{Ba}, \mathrm{Y}, \mathrm{Ni}$ and $\mathrm{Nb}$ were present in the range of $20-900 \mu \mathrm{g} \mathrm{g}^{-1}$. The methodologies were developed by using standards made with a mixture of $\mathrm{SiO}_{2}$ and $\mathrm{Al}_{2} \mathrm{O}_{3}$ in (1:1) concentration. Multipoint standardization was carried out to establish the calibration curves for each analyte. The methodologies were validated using synthetic samples. The statistical t-test was performed in order to understand the reliability of the data obtained by EDXRF and D. C. Arc AES with a $95 \%$ confidence limit and 8 degrees of freedom. The Ftest was also performed to understand the variance of the measurements.

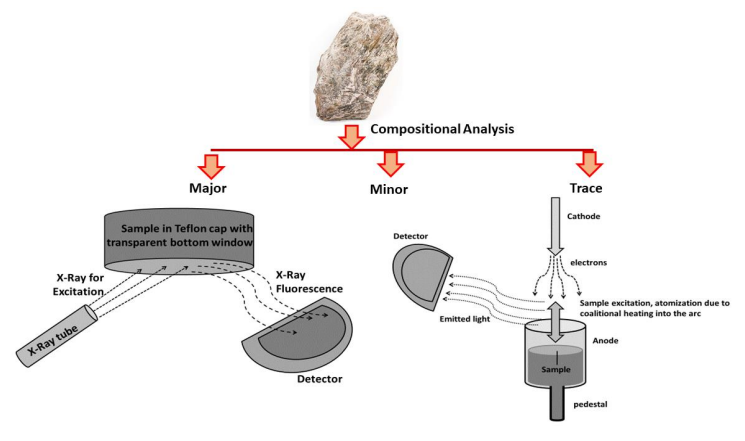

\section{INTRODUCTION}

Sillimanite is a polymorph of aluminosilicate metamorphosed sedimentary rock, having a bipyramidal orthorhombic crystal structure. ${ }^{1-3}$ The chains of Al-O octahedra along the z-axis linked sideways by chains of alternating Si-O tetrahedra are the main features of the sillimanite crystal. Due to the ability of the refractory mullite phase blended with the characteristics of high strength and resistance towards drastic physical and chemical stress even at high temperature, more than $90 \%$ of this mineral is being used in the manufacture of non-basic high alumina refractories, metals, glass, ceramics and cements. ${ }^{4-6}$ In the critical areas of the furnace, for steel degassing chambers, soaking pits, auxiliary pouring, and equipment used in the iron and steel industries these are the main consumers of sillimanite. Apart from refractory applications, the calcinated mineral is widely used in the fabrication of high-tension insulators, electrical ceramics, ceramic tile, honeycombs, high-temperature insulation, glass melt additives, and production of aluminium oxides, $\mathrm{Si}-\mathrm{Al}$ alloys, and metallic fibers. ${ }^{7-10}$ However, this variety of application and the high temperature physical, chemical and mechanical properties of sillimanite are highly influenced by the quality of the minerals, i.e., the presence of other elements, which also depends on the origin of the mineral. ${ }^{11,12}$

Tripathi et al. have investigated how the additive $\mathrm{TiO}_{2}$ can modify the mechanical properties of sillimanite by densification affecting the high temperature flexural strength of the aggregates. ${ }^{13}$ Gill et al. developed the Adaptive Neuro-Fuzzy Inference System-based simulation for understanding the material removal rate using stationary ultrasonic drilling by sillimanitebased ceramics. ${ }^{14}$ Tripathi et al. have also reported that $\mathrm{ZrO}_{2}$ additives on sillimanite improved the resistance characteristics for the thermal shock of the material. ${ }^{15}$ Goergen et al. investigated the 
rheological characteristics and deformation-induced polymorphic transformation in sillimanite. ${ }^{16}$ The mineral was reported to have a wide range of applications and many studies have been published on the physical, thermal, mechanical, and phase change as well as other characterizations of this mineral.

However, not much has been reported on its elemental characterization. Venkateswarulu et al. used proton-induced X-ray emission for trace level determination of coastal sand, including sillimanite, which was found to contain more than 20 analytes, including Sc, Zr, Ga, Br, Mo, Nb, Ce, La, and Dy. ${ }^{17}$ Pophare and Umathay reported the geochemical characterization of lithologies to understand the history of tectonic evolution, chemical homogeneity / heterogeneity in the light of major, minor, trace and rare earth element chemistry. ${ }^{18} \mathrm{~A}$ combination of inductively coupled plasma atomic emission spectrometry (ICP-AES) and flame atomic absorption spectrometry (AAS) has also been reported to be useful for the determination of analytes in mineral samples, such as $\mathrm{Al}, \mathrm{Ca}, \mathrm{Mg}, \mathrm{Cr}, \mathrm{V}, \mathrm{Si}, \mathrm{Fe}$ and Ti. ${ }^{19} \mathrm{~A}$ combination of neutron activation analysis and ICP-AES was used for the elemental characterization of serpentine of Indian origin, which also has high potential for nuclear shielding material. ${ }^{20}$ Sometimes, major, minor and trace constituents might have a detrimental influence on the quality of the mineral and hence, its application. For elemental characterization, a simple, rapid, multi-elemental, non-destructive, requirement of a small sample size, precise and reliable analytical technique is required. Ideally, it is exceedingly difficult to have all of these favorable characteristics in a single analytical technique. Moreover, a reference material available for the reliable characterization of the mineral is often not available. ${ }^{21}$

In view of these limitations, a combination of two distinct multielemental analytical techniques has been used for the determination of the metallic constituents in sillimanite at major, minor and trace levels. EDXRF, being rapid and non-destructive in nature, is capable of the estimation of major and minor levels of the constituents. ${ }^{22-26}$ However, this technique is totally incapable of trace level determination and of the determination of analytes having low $\mathrm{Z}$ values (B, Be, Li, etc.). On the contrary, D. C. Arc carrier distillation AES is the work horse for the determination of minor and trace level metallic constituents in powder samples used in a variety of industries, including the nuclear industry, where the trace level determination of impurities is very critical. ${ }^{26-29}$ However, this analytical technique is not suitable for major elements, is destructive in nature and associated with poor precision. Moreover, a plasma-based AES technique requires dissolution of the sample into a homogeneous solution, which is indeed difficult for geological samples. ${ }^{30,31}$ So, a combination of analytical techniques not only covers a wide range of analytes, but also gives the confidence in the values obtained by both techniques..$^{32-34}$ A statistical evaluation is mandatory to demonstrate the reliability and precision of the analyses; therefore, the statistical 't-test' and 'F-test' were performed..$^{35,36}$

\section{EXPERIMENTAL}

Materials. Multielemental standard solutions and individual Specpure solutions of the analytes were used in the present investigation (E-Merck, Germany). High purity $\mathrm{Al}_{2} \mathrm{O}_{3}$ and $\mathrm{SiO}_{2}$ powder was procured from Sigma Aldrich (USA) and $\mathrm{AgCl}$ from SPEX Industries (USA).

Instrumentation. The EDXRF spectrometric investigation was carried out using the Jordan Valley EX3600M spectrometer. The instrument has a stabilized X-ray tube and $\mathrm{Rh}$ as the X-ray source. The X-ray irradiation was carried out in normal air atmosphere and at room temperature. The $\mathrm{Si}(\mathrm{Li})$ detector, coupled with a multichannel analyzer, was used as the detection system. ${ }^{37}$ The maximum resolution of the instrument can be quoted as $0.139 \mathrm{keV}$ at $\mathrm{Mn}-\mathrm{K} \alpha(5.9 \mathrm{keV})$. Prior to analysis, the samples and standards were ground well to make a completely homogeneous powder with a large surface area. An amount of $500 \mathrm{mg}$ of the powder were put on a Teflon sample holder assembly. The EDXRF instrumental parameters were optimized for the present investigation and are summarized in Table 1.

D.C. Arc carrier distillation AES. Direct current arc carrier distillation atomic emission spectrometry was carried out using a D.C. Arc AES (Arcos FHS12 ICP-AES) instrument procured from Spectro Arcos, Germany. ${ }^{38,} 39$ The instrument has a dual excitation source in the form of D.C. Arc and inductively coupled plasma (ICP). The array of the charge coupled device (CCD) is used as the detection system. The sample introduction assembly, cup type anode, made of high purity graphite with ASTM designation E-130-66 type S-2, was used along with the cylindrical cathode having one sharp side and a cylindrical pedestal, all made of high purity graphite. ${ }^{40}$ Table 1 summarizes the instrumental parameters used in the present case.

Table 1. The Optimized Experimental Parameters for EDXRF and D. C. Arc AES Instruments

\begin{tabular}{ll}
\hline Parameter & Value \\
\hline EDXRF & \\
Station no. & $12-\mathrm{Cu}$ \\
Filter & $4-\mathrm{Fe}$ \\
Emission current, $\mu \mathrm{A}$ & 100 \\
High voltage, $\mathrm{kV}$ & 17 \\
Present time, $\mathrm{s}$ & 100 \\
Atmosphere & $\mathrm{Air}$ \\
Energy, keV & 40 \\
Throughput & High \\
Colorimeter & None \\
\hline $\begin{array}{l}\text { D. } \boldsymbol{C} \text {. } \text { Arc } \boldsymbol{A E S} \\
\text { Optical Mounting } \\
\text { Type of grating }\end{array}$ & Paschen-Runge \\
$\begin{array}{l}\text { Density of grooves in } \\
\text { dispersion element, } / \mathbf{m m}\end{array}$ & Holographic \\
Wavelength range, $\mathbf{n m}$ & 1800 \\
Resolution (FWHM) of the & \\
spectrometer & $130-800$ \\
Thermal isolation & $0.01 \mathrm{~nm}$ from $130-450 \mathrm{~nm}$ \\
Detector & $0.02 \mathrm{~nm}$ from $450-800 \mathrm{~nm}$ \\
& $30 \pm 1^{\circ} \mathrm{C}$ \\
\hline
\end{tabular}




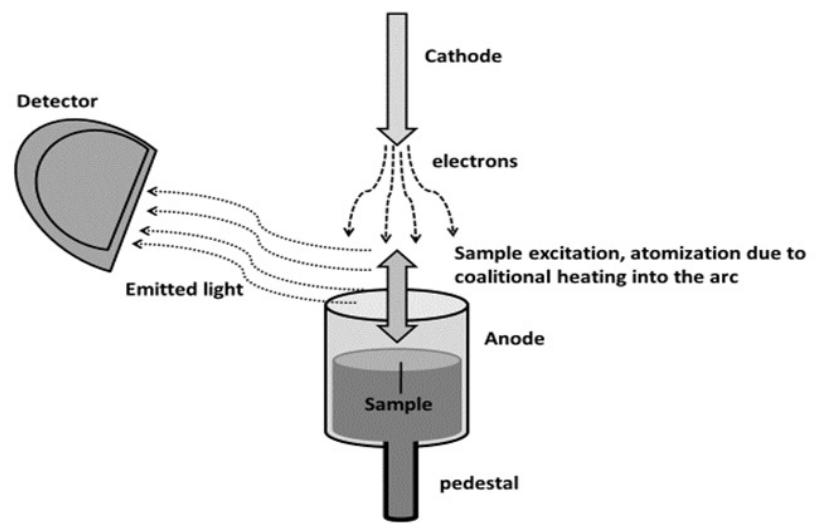

(a)

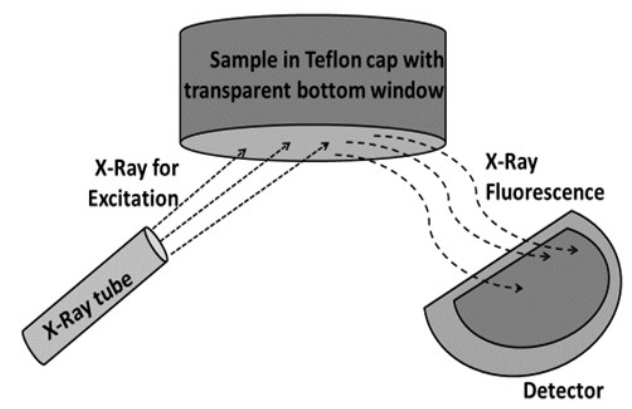

(b)

Fig. 1 (a) Schematic presentation of the sample introduction assembly in D. C. Arc carrier distillation AES; (b) The schematic presentation of the sample introduction system in EDXRF system.

Table 2. A Comparative Evaluation of The Analytical Performance of The Analytes in $\mathrm{A}$ Matrix $\mathrm{Al}_{2} \mathrm{O}_{3}: \mathrm{SiO}_{2}(1: 1)$

\begin{tabular}{|c|c|c|c|c|c|c|c|c|}
\hline \multirow{2}{*}{ Analytes } & \multicolumn{2}{|c|}{ Detection limit $\left(\mu \mathrm{g} \mathrm{g}^{-1}\right)$} & \multicolumn{2}{|c|}{ Sensitivity (counts $/ \mu \mathrm{g} \mathrm{g}^{-1}$ ) } & \multicolumn{2}{|c|}{ Precision (\% RSD) } & \multicolumn{2}{|c|}{ Regression coefficient $\left(\chi^{2}\right)$} \\
\hline & EDXRF & D. C. Arc AES & EDXRF & D. C.Arc AES & EDXRF & D. C. Arc AES & EDXRF & D. C. Arc AES \\
\hline $\mathbf{N a}$ & 30 & 5 & 28 & 41 & 8.2 & 18 & 0.9987 & 0.9991 \\
\hline $\mathbf{P b}$ & 45 & 10 & 23 & 37 & 6.3 & 16 & 0.9976 & 0.9935 \\
\hline Tb & 50 & 10 & 20 & 37 & 5.1 & 20 & 0.9996 & 0.9966 \\
\hline Mn & 25 & 5 & 31 & 40 & 4.9 & 17 & 0.9951 & 0.9985 \\
\hline $\mathbf{V}$ & 40 & 20 & 24 & 31 & 5.2 & 19 & 0.9932 & 0.9997 \\
\hline $\mathbf{T i}$ & 45 & 20 & 21 & 30 & 6.6 & 20 & 0.9996 & 0.9948 \\
\hline Ca & 35 & 5 & 22 & 43 & 5.9 & 18 & 0.9937 & 0.9985 \\
\hline Ba & 50 & 10 & 19 & 39 & 6.7 & 14 & 0.9991 & 0.9993 \\
\hline Mo & 50 & 40 & 18 & 32 & 7.4 & 16 & 0.9960 & 0.9921 \\
\hline $\mathbf{Y}$ & 50 & 40 & 19 & 35 & 7.3 & 15 & 0.9999 & 0.9928 \\
\hline $\mathbf{N i}$ & 40 & 5 & 22 & 44 & 5.9 & 19 & 0.9966 & 0.9948 \\
\hline $\mathbf{N b}$ & 40 & 10 & 21 & 38 & 6.3 & 20 & 0.9934 & 0.9998 \\
\hline Zn & 40 & 5 & 20 & 45 & 5.9 & 18 & 0.9901 & 0.9996 \\
\hline Eu & 30 & 80 & 30 & 40 & 7.7 & 19 & 0.9908 & 0.9930 \\
\hline Al & 35 & 5 & 24 & 43 & 4.9 & 18 & 0.9956 & 0.9922 \\
\hline $\mathrm{Si}$ & 40 & 20 & 20 & 35 & 5.5 & 17 & 0.9914 & 0.9987 \\
\hline
\end{tabular}

Method. The sample and standards were heated to their most stable refractory oxides. The powder samples were ground using mortar and pestle. For D. C. Arc AES, 5\% $\mathrm{AgCl}$ was used as the carrier. ${ }^{41}$ The carrier $\mathrm{AgCl}$ was used for physical separation of the major matrix from the analytes. Fig. 1 (a) shows the sample introduction system schematically, where the anode contains the sample charge, while the pointer cathode is at the top. The distance kept between these two electrodes was $4 \mathrm{~mm}$. This arc gap was decided based on previous literature. ${ }^{26,27,42,43}$

Sillimanite $\left(\mathrm{Al}_{2} \mathrm{SiO}_{5}\right)$, a mixture of $\mathrm{Al}_{2} \mathrm{O}_{3}$ and $\mathrm{SiO}_{2}$ with a composition of (1:1), was taken as the matrix element of the standards. To the powder, appropriate aliquots of multi-elemental solution were added to prepare the standards.

In case of EDXRF, the powder was put into the Teflon sample chamber, which had a transparent mylar bottom window. A schematic of the sample introduction system is shown in Fig. 1(b).

\section{RESULTS AND DISCUSSIONS}

Although many mechanical, physical, thermal and phase characterizations have been attempted for sillimanite, not much effort has been made for elemental characterization. Some reports are certainly available using inductively coupled plasma atomic emission spectrometry, mass spectrometry, and atomic absorption spectrometry. ${ }^{44-46}$ The wet route of analysis requires the cumbersome step of sample dissolution. However, neither D. C. Arc AES nor EDXRF has been attempted for the elemental characterization of sillimanite. It has been demonstrated that neither D. C. Arc carrier distillation AES nor EDXRF is a standalone technique for the overall elemental characterization, and that the combination of both methods is better.

Method optimization and validation. Table 2 shows a comparative evaluation of the analytical performance. For D. C. Arc AES, the following lines were chosen: $\mathrm{Na} 588.9 \mathrm{~nm}, \mathrm{~Pb} 283.3$ nm, Tb $321.890 \mathrm{~nm}$, Mn $257.6 \mathrm{~nm}$, V $318.5 \mathrm{~nm}$, Ti $498.1 \mathrm{~nm}$, 
Ca 396.8 nm, Ba 455.404 nm, Mo 202.0 nm, Y 371.029 nm, Ni 305.0 nm, Nb 210.943 nm, Zn 213.5 nm, Eu 393.048 nm, Al 308.2 $\mathrm{nm}$, and Si $288.1 \mathrm{~nm}$. Similarly, for EDXRF, the following analytical lines were chosen: $\mathrm{Na} 1.041 \mathrm{keV}, \mathrm{Pb} 10.549 \mathrm{keV}, \mathrm{Tb}$ $6.273 \mathrm{keV}$, Mn $5.899 \mathrm{keV}, \mathrm{V} 4.952 \mathrm{keV}$, Ti $4.510 \mathrm{keV}$, Ca 3.690 $\mathrm{keV}$, Ba $4.466 \mathrm{keV}$, Mo $17.478 \mathrm{keV}$, Y $1.924 \mathrm{keV}$, Ni $7.477 \mathrm{keV}$, $\mathrm{Nb} 2.169 \mathrm{keV}, \mathrm{Zn} 8.367 \mathrm{keV}$, Eu $5.849 \mathrm{keV}, \mathrm{Al} 1.487 \mathrm{keV}$ and Si $1.740 \mathrm{keV}$. In EDXRF, the detection limits (DL) for Mn were found to be lowest among all of the analytes and was equal to 25 $\mu \mathrm{g} \mathrm{g}^{-1}$, while for $\mathrm{Na}$ and $\mathrm{Eu}$ it was $30 \mu \mathrm{g} \mathrm{g}^{-1}$; for $\mathrm{Ca}$ and $\mathrm{Al}$ it was $35 \mu \mathrm{g} \mathrm{g}^{-1}$; for $\mathrm{V}, \mathrm{Nb}, \mathrm{Si}, \mathrm{Zn}$, and $\mathrm{Ni}$ it was $40 \mu \mathrm{g} \mathrm{g}^{-1}$; for $\mathrm{Pb}$ and $\mathrm{Ti}$ it was $45 \mu \mathrm{g} \mathrm{g}^{-1}$; and for $\mathrm{Tb}, \mathrm{Ba}, \mathrm{Y}$, the DL was found to be the highest at $50 \mu \mathrm{g} \mathrm{g}^{-1}$.

However, in case of D. C. Arc AES, the detection limit was much lower than that obtained by EDXRF. For Na, Mn, Ca, Ni and $\mathrm{Zn}$, the $\mathrm{DL}$ was at $5 \mu \mathrm{g} \mathrm{g}^{-1}$; for $\mathrm{Pb}, \mathrm{Tb}, \mathrm{Ba}, \mathrm{Nb}$ at $10 \mu \mathrm{g} \mathrm{g}^{-1}$; for $\mathrm{V}, \mathrm{Ti}, \mathrm{Si}$ at $20 \mu \mathrm{g} \mathrm{g}^{-1}$; and for Mo, Y at $40 \mu \mathrm{g} \mathrm{g}^{-1}$. For Eu, the DL was at $80 \mu \mathrm{g} \mathrm{g}^{-1}$. In case of D. C. Arc AES and due to the formation of the highly refractory oxides by $\mathrm{Eu}, \mathrm{V}, \mathrm{Ti}, \mathrm{Mo}, \mathrm{Y}$ and $\mathrm{Si}$, their volatility to reach the arc was very poor and hence, their DL was also poorer compared to the other analytes in the matrix. The DL for $\mathrm{Si}$ was calculated in the $\mathrm{Al}_{2} \mathrm{O}_{3}$ matrix only, while for $\mathrm{Al}$ it was calculated in the $\mathrm{SiO}_{2}$ matrix.

The standard deviation values were calculated based on 10 replicate measurements using Equation (1) as follows:

$$
s=\sqrt{\sum_{n} \frac{\left(x_{i}-<x>\right)^{2}}{n-1}}
$$

where $\mathrm{s}$ is the standard deviation, $\mathrm{x}_{\mathrm{i}}$ is each replicate value, $<\mathrm{x}>$ is the average of 10 replicate measurements, and $n-1$ is the degree of freedom.

The relative standard deviation was calculated in Equation (2) as follows:

$$
\% R S D=\frac{s}{<x>} \times 100 \%
$$

Eq. (2)
Since ' $s$ ' was a function of $<x>$, therefore, to avoid such contribution, the precision values were expressed as \% RSD. The RSD for all of the analytes in EDXRF were found to be less than $10 \%$, while for D. C. Arc it was in the range of $15-20 \%$. The major issue for the poor precision was reported to be due to arc wandering.

For EDXRF, the linear dynamic range (LDR) for $\mathrm{Na}, \mathrm{Mn}, \mathrm{Ca}$, $\mathrm{Ba}, \mathrm{Ni}$, and $\mathrm{Al}$ was found to be in the range between their $\mathrm{DL}$ and $10,000 \mu \mathrm{g} \mathrm{g}^{-1}$. For $\mathrm{Si}$ and $\mathrm{Al}$, it varied from their DL up to $40 \%$. Beyond that, the calibration curves were found to deviate from linearity. For the rest of the analytes, the LDR varied from their DL to $5000 \mu \mathrm{g} \mathrm{g}^{-1}$. However, for D. C. Arc AES, the calibration curves were found to be sigmoid in nature and hence, $\log$ intensity vs. $\log$ analyte concentration was used in order to achieve the LDR. $\mathrm{Na}, \mathrm{Mn}, \mathrm{Ca}, \mathrm{Ni}, \mathrm{Pb}, \mathrm{Tb}, \mathrm{Ba}, \mathrm{Nb}$, and $\mathrm{Zn}$ were found to have LDR from their DL to $500 \mu \mathrm{g} \mathrm{g}^{-1}$; whereas for $\mathrm{V}, \mathrm{Ti}, \mathrm{Si}, \mathrm{Mo}, \mathrm{Y}$, and $\mathrm{Eu}$, the LDR varied from their DL to $800 \mu \mathrm{g} \mathrm{g}^{-1}$.

Table 3 summarizes the validation of the developed analytical methodologies using synthetic samples. In synthetic sample 1, on the matrix $\mathrm{SiO}_{2}-\mathrm{Al}_{2} \mathrm{O}_{3}$ (1:1) mixture, aliquots of multi-elemental aqueous standards were added in such a way, so that the final concentration in the powder samples would be $100 \mu \mathrm{g} \mathrm{g}^{-1}$, while for the synthetic sample 2 it was $200 \mu \mathrm{g} \mathrm{g}^{-1}$. In case of Mo, Y, V, $\mathrm{Ti}$, etc., their corresponding metal oxides are highly refractory in nature; hence, they have a poorer DL. The estimations of most of the analytes were within the acceptable limits, and the data obtained by both techniques were also comparable. The mean of the replicate measurements in both sides was found to fall withinin the expected mean (added values). This observation apparently indicates that there is no determinate error/bias during replicate measurements. The observed ranges are due to random error. The confidence intervals for D. C. Arc AES were found to be wider in comparison to EDXRF.

\begin{tabular}{|c|c|c|c|c|c|c|}
\hline \multirow{2}{*}{ Analytes } & \multicolumn{3}{|c|}{ Synthetic sample 1} & \multicolumn{3}{|c|}{ Synthetic sample 2} \\
\hline & As prepared & EDXRF & D. C. Arc AES & As prepared & EDXRF & D. C. Arc AES \\
\hline $\mathbf{N a}$ & 100 & $94 \pm 6$ & $85 \pm 15$ & 200 & $185 \pm 18$ & $220 \pm 30$ \\
\hline $\mathbf{P b}$ & 100 & $103 \pm 8$ & $110 \pm 20$ & 200 & $190 \pm 15$ & $218 \pm 35$ \\
\hline $\mathbf{T b}$ & 100 & $97 \pm 8$ & $98 \pm 15$ & 200 & $211 \pm 18$ & $180 \pm 30$ \\
\hline Mn & 100 & $96 \pm 9$ & $111 \pm 18$ & 200 & $215 \pm 20$ & $175 \pm 34$ \\
\hline $\mathbf{V}$ & 100 & $108 \pm 9$ & $92 \pm 16$ & 200 & $188 \pm 16$ & $230 \pm 40$ \\
\hline $\mathbf{T i}$ & 100 & $99 \pm 8$ & $96 \pm 17$ & 200 & $190 \pm 15$ & $215 \pm 35$ \\
\hline Ca & 100 & $104 \pm 8$ & $100 \pm 18$ & 200 & $193 \pm 18$ & $170 \pm 35$ \\
\hline $\mathbf{B a}$ & 100 & $97 \pm 8$ & $93 \pm 15$ & 200 & $209 \pm 15$ & $190 \pm 30$ \\
\hline Mo & 100 & $105 \pm 9$ & $104 \pm 18$ & 200 & $201 \pm 16$ & $205 \pm 35$ \\
\hline $\mathbf{Y}$ & 100 & $100 \pm 10$ & $90 \pm 17$ & 200 & $185 \pm 17$ & $210 \pm 30$ \\
\hline $\mathbf{N i}$ & 100 & $101 \pm 8$ & $99 \pm 17$ & 200 & $190 \pm 18$ & $225 \pm 35$ \\
\hline $\mathbf{N b}$ & 100 & $98 \pm 9$ & $109 \pm 15$ & 200 & $196 \pm 18$ & $172 \pm 33$ \\
\hline Zn & 100 & $108 \pm 7$ & $102 \pm 15$ & 200 & $190 \pm 15$ & $220 \pm 35$ \\
\hline Eu & 100 & $95 \pm 8$ & $110 \pm 20$ & 200 & $205 \pm 19$ & $180 \pm 35$ \\
\hline
\end{tabular}

Table 3. Analysis of Synthetic Samples Prepared by $\mathrm{Al}_{2} \mathrm{O}_{3}-\mathrm{SiO}_{2}$ in 1:1 Ratio as Matrix 
Table 4. A Comparative Characterization of Sillimanite by EDXRF and D. C. Arc AES

\begin{tabular}{cccc}
\hline Analytes & $\begin{array}{c}\text { EDXRF } \\
\left(\boldsymbol{\mu g} \mathbf{~ g}^{-1}\right)\end{array}$ & $\begin{array}{c}\text { D. C. Arc AES } \\
\left(\boldsymbol{\mu g} \mathbf{~ g}^{-1}\right)\end{array}$ & $\begin{array}{c}\text { ICP-AES } \\
\left(\boldsymbol{\mu g ~ g}^{-1}\right)\end{array}$ \\
\hline $\mathbf{N a}$ & $60 \pm 3$ & $50 \pm 9$ & $54 \pm 3$ \\
$\mathbf{P b}$ & $780 \pm 30$ & $850 \pm 120$ & $600 \pm 30$ \\
$\mathbf{T b}$ & $450 \pm 20$ & $370 \pm 70$ & $400 \pm 20$ \\
$\mathbf{M n}$ & $400 \pm 20$ & $330 \pm 60$ & $380 \pm 20$ \\
$\mathbf{V}$ & $260 \pm 15$ & $250 \pm 40$ & $260 \pm 10$ \\
$\mathbf{T i}$ & $500 \pm 30$ & $600 \pm 90$ & $540 \pm 20$ \\
$\mathbf{C a}$ & $320 \pm 15$ & $280 \pm 50$ & $290 \pm 20$ \\
$\mathbf{B a}$ & $170 \pm 10$ & $200 \pm 40$ & $180 \pm 10$ \\
$\mathbf{M o}$ & $73 \pm 5$ & $65 \pm 10$ & $68 \pm 4$ \\
$\mathbf{Y}$ & $50 \pm 5$ & $50 \pm 8$ & $48 \pm 3$ \\
$\mathbf{N i}$ & $50 \pm 4$ & $52 \pm 4$ & $50 \pm 3$ \\
$\mathbf{N b}$ & $50 \pm 7$ & $50 \pm 4$ & $51 \pm 3$ \\
$\mathbf{Z n}$ & $\mathrm{BDL}$ & $10.0 \pm 0.9$ & $9.9 \pm 0.4$ \\
$\mathbf{E u}$ & $30 \pm 2$ & $\mathrm{BDL}$ & $27 \pm 1$ \\
$\mathbf{A l}$ & $29 \%$ & $22 \%$ & $26 \%$ \\
$\mathbf{S i}$ & $14 \%$ & $12 \%$ & $13.5 \%$ \\
\hline
\end{tabular}

Analysis of actual sample. Table 4 summarizes the analytical results for sillimanite. The elements $\mathrm{Na}, \mathrm{Pb}, \mathrm{Tb}, \mathrm{Mn}, \mathrm{V}, \mathrm{Ti}, \mathrm{Ca}, \mathrm{Ba}$, $\mathrm{Mo}, \mathrm{Y}, \mathrm{Ni}$ and $\mathrm{Nb}$ as estimated by both techniques were found to be present at minor or trace level. Also, $5 \mu \mathrm{g} \mathrm{g}^{-1} \mathrm{~B}(249.7 \mathrm{~nm})$ and $8 \mu \mathrm{g} \mathrm{g}^{-1} \mathrm{Be}(234.4 \mathrm{~nm})$ were detected by D. C. Arc AES, while they could not be detected by EDXRF. Even though both D. C. Arc and EDXRF were used to estimate $\mathrm{Al}$ and $\mathrm{Si}$ as major elements, negative bias is expected for D. C. Arc AES and hence, the EDXRF data $(29 \% \mathrm{Al}$ and $14 \% \mathrm{Si})$ were more reliable. A 10 $\mu \mathrm{g} \mathrm{g}{ }^{-1} \mathrm{Zn}(213.5 \mathrm{~nm})$ was also estimated by D. C. Arc AES; however, it could not be detected by EDXRF as the detection limit was estimated as $40 \mu \mathrm{g} \mathrm{g}^{-1}$ for $\mathrm{Zn}\left(\mathrm{K}_{\alpha}\right)$ by EDXRF. On the other hand, $30 \mu \mathrm{g} \mathrm{g}^{-1} \mathrm{Eu}$ was estimated by EDXRF using its L $\alpha$; however, it could not be detected by D. C. Arc AES. This was attributed to the formation of the highly refractory oxide $\mathrm{Eu}_{2} \mathrm{O}_{3}$, resulting in poorer DL for Eu $\left(80 \mu \mathrm{g} \mathrm{g}^{-1}\right)$ by D. C. Arc AES. the elements $\mathrm{Na}, \mathrm{Mo}, \mathrm{Y}, \mathrm{Ni}$ and $\mathrm{Nb}$ were found to be present in the concentration range of $45-80 \mu \mathrm{g} \mathrm{g}^{-1} ; \mathrm{Ba}, \mathrm{Ca}, \mathrm{V}, \mathrm{Mn}, \mathrm{Tb}$ were present in the concentration range of $150-450 \mu \mathrm{g} \mathrm{g}^{-1}$; while $\mathrm{Pb}$ and Ti were found to be more than $500 \mu \mathrm{g} \mathrm{g}^{-1}$. The results obtained by both techniques were in good agreement.

Statistical evaluation. The analytical results were subjected to statistical evaluation for their variation in terms of the Student's $t$ test using Equation (3):

$$
\mu=\langle x\rangle \pm \frac{s \cdot t}{\sqrt{N}}
$$

where $\mu$ is the theoretical mean, $\mathrm{t}$ is the $\mathrm{t}$ value.

Based on null hypothesis, there is no difference between the mean values obtained for each analyte in both techniques as shown with Equation (4):

$$
H_{0}^{\text {null hypothesis }}=H_{D . C . A r c A E S}=H_{E D X R F}
$$

Alternatively, the mean values are different, i.e., as shown with Equation (5):

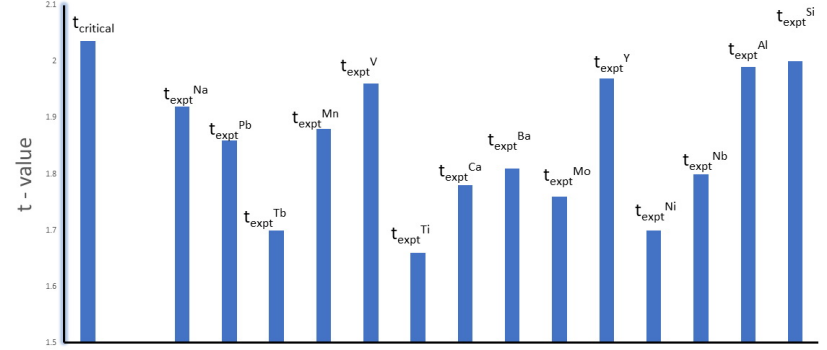

Fig. 2 Student t-test for the analysis of sillimanite samples for the metallic constituents by D. C. Arc AES and EDXRF technique.

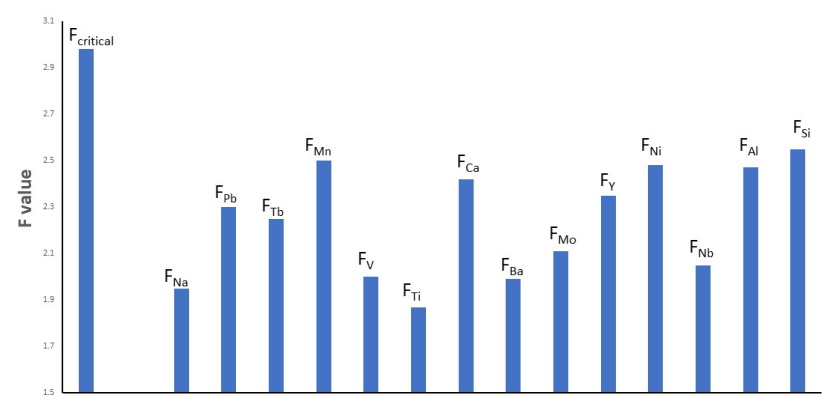

Fig. 3 F-test for the analysis of sillimanite samples for the metallic constituents by D. C. Arc AES and EDXRF technique.

$H_{1}^{\text {Alternative to null hypothesis }}=H_{D . C . A r c ~ A E S} \neq H_{E D X R F}$ Eq.

The ' $\mathrm{t}$ ' values were calculated with the degree of freedom 8 $\left(t_{\text {expt }}^{8,95 \%}\right)$ and with a $95 \%$ confidence level (Fig. 2). Since $t_{\text {expt }}^{8,95 \%}<t_{\text {critical }}^{8,95 \%}$, the null hypothesis was found to be true. The variation in analytical results was within statistical variation and acceptable with $95 \%$ confidence level.

Similarly, the F-test was also carried out at degrees of freedom 10 with a $95 \%$ confidence level. In accordance with null hypothesis, Equation (6) shows:

$$
S_{D . C . A r C A E S}{ }^{2}=S_{E D X R F}{ }^{2}
$$

where the terms correspond to the variance of the specific techniques.

The alternative hypotheses are shown in Equation (7) and (8):

$$
\begin{gathered}
s_{D . C . A r C A E S^{2}} \neq s_{E D X R F}{ }^{2} \\
F_{\text {expt }}=\frac{s_{D . C . A r C A E S}^{2}}{s_{E D X R F}^{2}}
\end{gathered}
$$

$F_{\text {critical }}$ was 2.98 , while the experimentally determined $\mathrm{F}$ values were found to be well below the critical value (Fig. 3) and hence, the methods are precise.

Fig. 4 (a) shows the concentration ranges of the analytes present in different sillimanites, while Fig. 4 (b) depicts the same for the major elements of $\mathrm{Al}$ and $\mathrm{Si}$. For $\mathrm{Na}, \mathrm{Mo}, \mathrm{Y}, \mathrm{Ni}$, and $\mathrm{Pb}$, where the concentration range was found to be $50-60 \mu \mathrm{g} \mathrm{g}^{-1}$; for Ba it was in the range $170-190 \mu \mathrm{g} \mathrm{g}^{-1}$; for $\mathrm{Ca}$ and $\mathrm{V}$ it was $250-260 \mu \mathrm{g} \mathrm{g}^{-1}$; for 


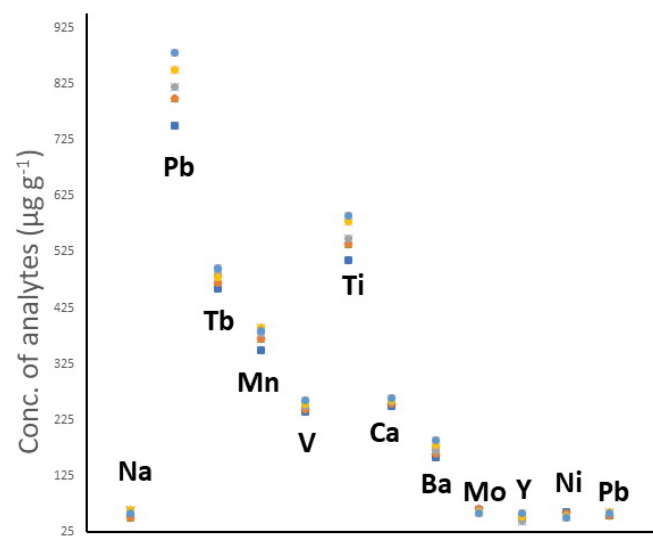

(a)

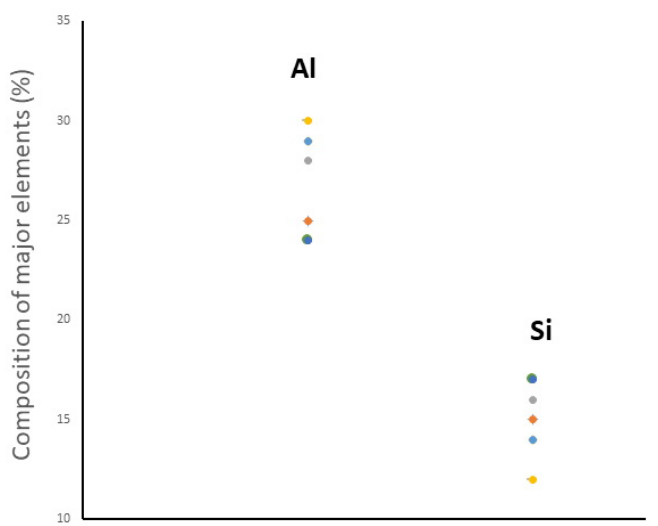

(b)

Fig. 4 Concentration range of major, minor and trace elements present in sillimanite collected from the different regions.

Mn the variation was $350-390 \mu \mathrm{g} \mathrm{g}^{-1}$. In the case of $\mathrm{Tb}$, $\mathrm{Ti}$ and $\mathrm{Pb}$, the concentration range was $450-500 \mu \mathrm{g} \mathrm{g}^{-1}, 510-590 \mu \mathrm{g} \mathrm{g}^{-1}$, and $750-880 \mu \mathrm{g} \mathrm{g}^{-1}$, respectively. The $\mathrm{Al}$ concentration was found to vary between $24-30 \%$, while Si was found to vary within $12-18 \%$.

\section{CONCLUSIONS}

Analytical methodologies were developed for the determination of major, minor and trace metallic constituents in sillimanite using the AES and XRF techniques. The $\mathrm{Al}_{2} \mathrm{O}_{3}-\mathrm{SiO}_{2}$ (1:1) powder mixture was used to prepare the multipoint standards. The DLs were found to be poorer in case of EDXRF. For Eu and other analytes, which form highly refractory oxides, the DL was poorer with D. C. Arc AES. For Na, Mo, Y, Ni and Nb, the DLs were found to be in the concentration range from $45-80 \mu \mathrm{g} \mathrm{g}^{-1}$; for $\mathrm{Ba}$, $\mathrm{Ca}, \mathrm{V}, \mathrm{Mn}, \mathrm{Tb}$ in the concentration range from 150-450 $\mu \mathrm{g} \mathrm{g}^{-1} ; \mathrm{Pb}$ and $\mathrm{Ti}$ were found to be more than $500 \mu \mathrm{g} \mathrm{g}^{-1}$. The tcritical was found to be more than texperimental, revealing the reliability of the data. The F-test revealed that the variance was within the allowed statistical limit.

\section{AUTHOR INFORMATION}

\section{Corresponding Author}

*A. Sengupta

Email address: arijita@barc.gov.in; arijitbarc@gmail.com

Notes

The authors declare no competing financial interest.

\section{ACKNOWLEDGMENTS}

The authors wish to acknowledge Dr. R. M. Kadam, Head, Actinide Spectroscopy Section, RCD, and Dr. P.K. Pujari, GD, RC \& I G and Head RCD, BARC, Mumbai, India.

\section{REFERENCES}

1. H. Yang, R. M. Hazen, L. W. Finger, C. T. Prewitt, and R. T. Downs, Phys. Chem. Miner., 1997, 25, 39-47. https://doi.org/10.1007/s002690050084

2. M. T. Vaughan and D. J. Weidner, Phys. Chem. Miner., 1978, 3, 133-144. https://doi.org/10.1007/BF00308117

3. D. R. Peacor, R. C. Rouse, and E. S. Grew, Am. Mineral., 1999, 84, 1152-1161. https://doi.org/10.2138/am-1999-7-818

4. S. Kumar, S. K. Das, and P. K. Daspoddar, Ceram. Int., 2003, 29, 139-144. https://doi.org/10.1016/S0272-8842(02)00095-0

5. M. Vijay, P. V. Ananthapadmanabhan, K. Ramachandran, G. Hiremath, C. B. Mathai, B. Nalini, and B. C. Pillai, Int. J. Refract. Met. H., 2013, 36, 174-178. https://doi.org/10.1016/j.jjrmhm.2012.08.012

6. A Tomba, M. A. Camerucci, G. Urretavizcaya, A. L. Cavalieri, M. A. Sainz, and A. Caballero, Ceram. Int., 1999, 25, 245-252. https://doi.org/10.1016/S0272-8842(98)00031-5

7. G. G. Lepezin, S. A. Kargopolov, and V. Yu. Zhirakovskii, Russ. Geol Geophys., 2010, 51, 1247-1256. https://doi.org/10.1016/j.rgg.2010.11.004

8. S. Sharma, T. Nanda, and O. P. Pandey, Tribol. Int., 2018, 123, 142-154. https://doi.org/10.1016/j.triboint.2017.12.031

9. M. M. S. Al Bosta, K.-J. Ma, and H.-H Chien, Infrared Phys. Technol., 2013, 60, 323-334. https://doi.org/10.1016/j.infrared.2013.06.006

10. P. Kumar, M. Nath, A. Ghosh, and S. Tripathi, Trans. Nonferrous Met. Soc. China, 2016, 26, 2397-2403. https://doi.org/10.1016/S1003-6326(16)64329-7

11. B. L. Dutrow, C. T. Foster JR, and D. J. Henry, Am. Mineral., 1999, 84, 794-805. https://doi.org/10.2138/am-1999-5-615

12. B. W. Evans and C. V. Guidotti, Contrib. Mineral Petrol., 1966, 12, 25-62. https://doi.org/10.1007/BF02651127

13. H. S. Tripathi and G. Banerjee, J. Euro. Ceram. Soc., 1998, 18, 2081-2087. https://doi.org/10.1016/S0955-2219(98)00149-6

14. S. S. Gill and J. Singh, Expert Syst. Appl., 2010, 37, 5590-5598. https://doi.org/10.1016/j.eswa.2010.02.054

15. H. S. Tripathi, S. K. Das, B. Mukherjee, A. Ghosh, and G. Banerjee, Ceram. Int., 2001, 27, 833-837. https://doi.org/10.1016/S02728842(01)00037-2

16. E. T. Goergen, D. L. Whitney, M. E. Zimmerman, and T. Hiraga, Tectonophys., 2008, 454, 23-35. https://doi.org/10.1016/j.tecto.2008.03.010

17. P. Venkateswarulu, C. Kasipathi, K. Srinivasa Rao, 
R. Venkateswara Rao, and T. R. Rautray, Inst. Sci. Technol., 2013, 41, 406-427. https://doi.org/10.1080/10739149.2012.757739

18. A. M. Pophare and R. M. Umathay, Gond. Geol. Magz., 2009, 24, 123-130. https://doi.org/5542712cocf23ff716835d44

19. R. Radhamani, P. Murugesan, A. Premadas, and P. K. Srivastava, Talanta, 2007, 71, 1932-1938. https://doi.org/10.1016/j.talanta.2006.08.031

20. A. Sengupta, B. Rajeswari, R. M. Kadam, and R. J. Kshirsagar, J. Radioanal. Nucl. Chem., 2012, 292, 903-908. https://doi.org/10.1007/s10967-011-1535-7

21. J. E. Gagnon, B. J. Fryer, I. M. Samson, and A. E. Williams-Jones, J. Anal. At. Spectrom., 2008, 23, 1529-1537. https://doi.org/10.1039/B801807N

22. A. Mohapatra, T. R. Rautray, V. Vijayan, R. K. Mohanty, and S. K. Dey, Aquaculture, 2007, 270, 552-558. https://doi.org/10.1016/j.aquaculture.2007.04.023

23. Z. L. L. Yeung, R. C. W. Kwok, and K. N. Yu, Appl. Radiat. Isotopes, 2003, 58, 339-346. https://doi.org/10.1016/S0969-8043(02)00351-2

24. H. Matsunami, K. Matsuda, S. Yamasaki, K. Kimura, Y. Ogawa, and Y. Miura, Soil Sci. Plant Nutr., 2010, 56, 530-540. https://doi.org/10.1111/j.1747-0765.2010.00489.x

25. G. M. Marcazzan, M. Ceriani, G. Valli, and R. VecchI, X-ray Spectrom., 2004, 33, 267-272. https://doi.org/10.1002/xrs.719

26. N. Pathak, V. C. Adya, S. K. Thulasidas, A. Sengupta, T. K. Seshagiri, and S. V. Godbole, At. Spectrosc., 2014, 35, 17-24.

27. A. Sengupta and V. C. Adya, At. Spectrosc., 2013, 34, 207-215.

28. B. Rajeswari, S. Pathak, Sk. Jayabun, N. Pathak, M. Mohapatra, A. Sengupta, and R. M. Kadam, At. Spectrosc., 2019, 40, 221-226. https://doi.org/10.46770/AS.2019.06.004

29. S. Pathak, Sk. Jayabun, B. Rajeswari, N. Pathak, M. Mohapatra, A. Sengupta, and R. M. Kadam, At. Spectrosc., 2019, 40, 215-220. https://doi.org/10.46770/AS.2019.06.003

30. T. H. Bell and C. Cuff, J. Metamorph. Geol., 1989, 7, 425-447. https://doi.org/10.1111/j.1525-1314.1989.tb00607.x

31. T. H. Bell and M. J. Rubenach, Tectonophys., 1983, 92, 171-194. https://doi.org/10.1016/0040-1951(83)90089-6
32. A. Sengupta, B. Rajeswari, and R. M. Kadam, Chem. Selects, 2020, 5, 3763-3769. https://doi.org/10.1002/slct.202000156

33. A. Sengupta, B. Rajeswari, and R. M. Kadam, J. Anal. At. Spectrom., 2020, 35, 169-177. https://doi.org/10.1039/C9JA00321E

34. A. Sengupta, S. K. Thulasidas, and V. Natarajan, J. Radioanal. Nucl. Chem., 2015, 303, 2421-2429. https://doi.org/10.1007/s10967-0143679-8

35. G. D. Ruxton, Behav. Ecol., 2006, 17, 688-690. https://doi.org/10.1093/beheco/ark016

36. P. Baldi and A. D. Long, Bioinformatics, 2001, 17, 509-519. https://doi.org/10.1093/bioinformatics/17.6.509

37. V. Natarajan, M. J. Kulkarni, N. K. Porwal, B. A. Dhawale, N. S. Hon, S. V. Godbole, and V. K. Manchanda, Nucl. Instrum. Meth. B., 2008, 266, 3290-3294. https://doi.org/10.1016/j.nimb.2008.04.011

38. A. Sengupta, T. Ippili, Sk. Jayabun, M. Singh, and S. K. Thulasidas, J. Radioanal. Nucl. Chem., 2016, 310, 59-67. https://doi.org/10.1007/s10967-016-4790-9

39. A. Sengupta, Y. Airan, S. K. Thulasidas, and V. Natarajan, At. Spectrosc., 2015, 36, 82-95.

40. L. S. Dale, Appl. Spectrosc., 1974, 28, 564-568. https://doi.org/10.1366/000370274774332010

41. A. G. I. Dalvi, C. S. Deodhar, T. K. Sheshagiri, M. S. Khalap, and B. D. Joshi, Talanta, 1978, 25, 665-668. https://doi.org/10.1016/00399140(78)80168-4

42. B. F. Scribner and H. R. Mullin, J. Res. Natl. Bur Stand., 1946, 37, 379-389. https://doi.org/jresv37n6p379_A1b

43. N. K. Porwal, A. A. Argekar, P. J. Purohit, A. G. Page, and M. D. Sastry, Fresenius' J. Anal. Chem., 1990, 338, 255-258. https://doi.org/10.1007/BF00323019

44. I. Mounteney, A. K. Burton, A. R. Farrant, M. J. Watts, S. J. Kemp, and J. M. Cook, J. Geochem. Explor, 2018, 184, 1-10. https://doi.org/10.1016/j.gexplo.2017.10.007

45. J. Rajendran, P. K. Thampi, and G. Balasubramanian, Anal. Lett., 2006, 39, 2297-2306. https://doi.org/10.1080/00032710600755587

46. P. Hannaker and H. Q. Lie, Talanta, 1984, 31, 1153-1157. https://doi.org/10.1016/0039-9140(84)80267-2 